\title{
ADDITIONAL NOTES ON MANITOBA'S LONG-LIVED GREAT HORNED OWL (BAND NUMBER 568-17752)
}

SPENCER G. SEALY, Department of Zoology, University of Manitoba, Winnipeg, MB R3T 2N2; JAMES C. DUNCAN, Manitoba Conservation, 200 Saulteaux Crescent, Winnipeg, MB R3J 3W5; and ROBERT W. NERO, 546 Coventry Road, Winnipeg, MB R3R 1B6

Much has been written about a Great Horned Owl that was banded in the Winnipeg suburb of Charleswood, Manitoba, on 20 December 1964 and found injured on 6 January 1992, a few blocks from the original banding site. $6,13,19$ Trapped and banded by Matt Dedrick, on Harold V. Hosford's banding permit (band number 568-17752), this bird was found over two decades later by a staff member of the Assiniboine Park Zoo who captured it on the zoo's property, thin and weak after an apparent collision with a moving vehicle on a nearby street. An irreparable fracture of the frontal bone on one orbit and a grossly distended eye led zoo staff to euthanize the bird. ${ }^{13}$

The specimen was delivered to the Úniversity of Manitoba Zoology Museum (UMZM) where it was kept frozen until October 2000, when Sealy prepared it as a study skin (Fig. 1) and catalogued it in the museum's avian collection (UMZM 2628). The frozen bird weighed $1125 \mathrm{~g}$, which was less than the bird's weight (1755 g) when it was banded and much less than the $2025 \mathrm{~g}$ it weighed when recaptured by Dedrick two years after banding on 24 December 1966 (Nero 1992). Upon dissection, the emaciated bird was determined to be a female, with the largest ova about $1 \mathrm{~mm}$ in diameter, confirming Dedrick's original determination of the bird's sex based on measurements. Dedrick (pers. comm. to Nero, 27 March 1992) had noted that the bird had nested for years in Assiniboine Park Forest, in urban Winnipeg, although

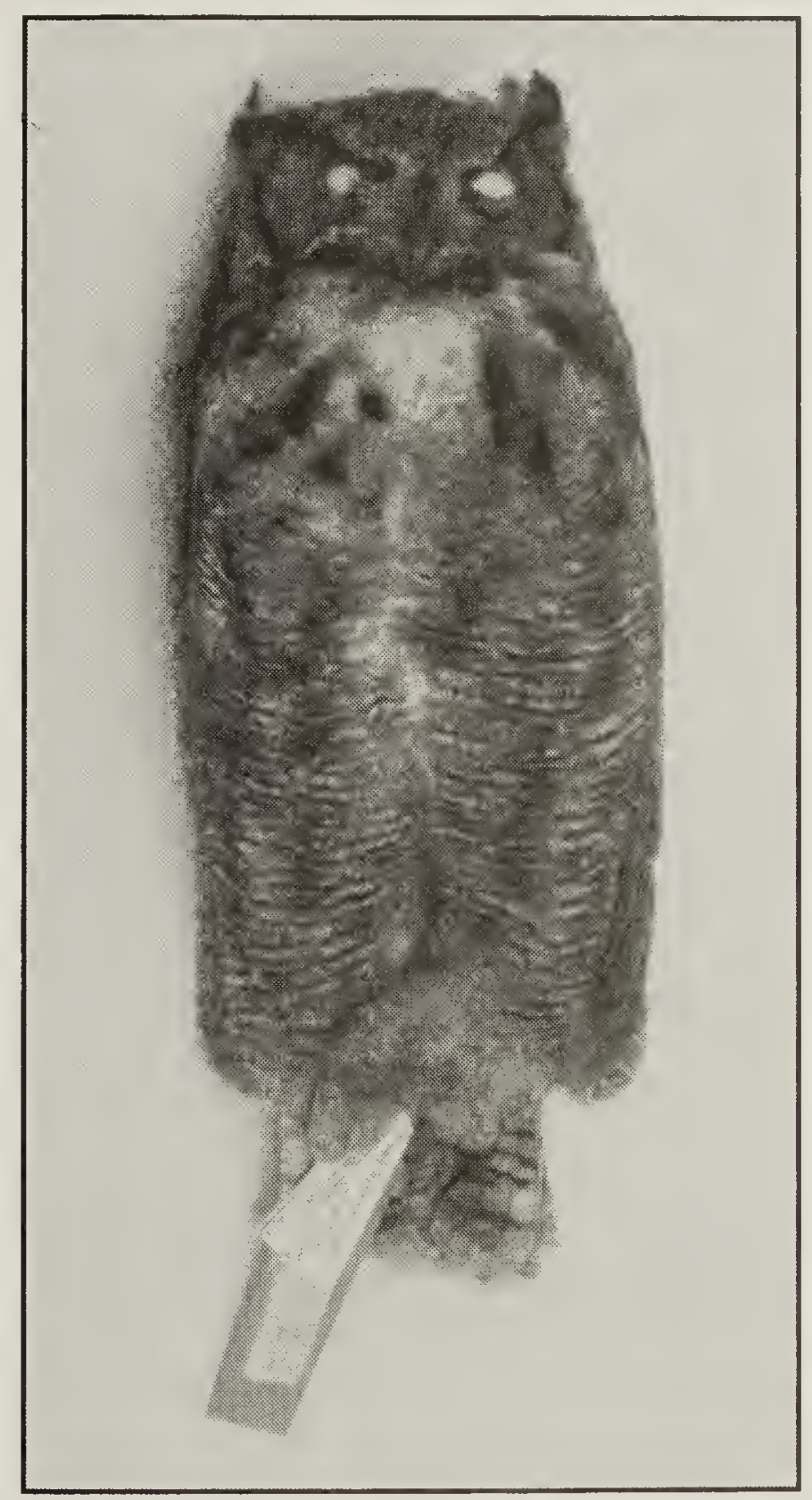

Figure 1. Great Horned Owl banded (number 568-17752) on 20 December 1964 in Winnipeg, Manitoba, and recovered near the original banding site on 6 January 1992.

this was never confirmed. Surviving the perils of living in an urban setting for so many years seems remarkable, ${ }^{13}$ although the threat of shooting, once so real in rural areas, was reduced. ${ }^{8.10}$ 
The variation in pattern and colouration of plumages of Great Horned Owls in Manitoba is pronounced. Most adults are pale with white legs and feet and gray facial discs, and probably are referable to the subspecies Bubo virginianus subarcticus, $, 8,15$ an example of which is illustrated on page 32 in P.A. Taverner's Birds of Canada. ${ }^{17}$ Of 27 specimens of the Great Horned Owl in the University of Manitoba Zoology Museum, salvaged from various sites in Manitoba and Saskatchewan, only this and one other specimen (UMZM 1292) showed the rich rufous markings of nominate $B . v$. virginianus. This subspecies ranges approximately from neighboring Minnesota across southern Ontario to Nova Scotia and south to Texas and Florida. ${ }^{8}$ It is distinguished from subarcticus by its "medium dark coloration with distinctive amount of redness in the plumage (p. 310)" 5 with rusty facial discs and legs and feet of tawny to buff with black bars (see also Fig. 1). A typical example of virginianus is depicted by John Crosby's illustration (Plate 42) in The Birds of Canada. ${ }^{5} \mathrm{~A}$ photograph of specimens representing three subspecies, including virginianus and subarcticus, is presented on page 67 of Ron Pittaway's treatise of the subspecies of the Great Horned Owl in Ontario. ${ }^{15}$

\section{Calculation of longevity}

There are two recognized types of longevity: potential longevity and realized longevity. ${ }^{12}$ As described by Krebs in his fifth edition of Ecology, the first is the maximum life span attainable by an individual and is a limit set by the individual's physiology, such that it dies of old age. ${ }^{12}$ But individuals seldom live under optimal conditions, except in captivity where they are less likely to be killed accidentally, succumb to disease or be eaten by predators. There is an unsubstantiated report of a captive Great Horned Owl that lived for 68 years!' Realized longevity, on the other hand, is the actual life span of an individual as measured in the field, which is then averaged for all individuals in a population living under real environmental conditions. $^{12}$

The age of owl number 568-17752 at the time of death was estimated to be at least 28 years, 7 months, as it was banded as an adult in 1964 and assumed to have hatched at least as early as the summer of $1963 . .^{13}$ This record was submitted to the North American Bird Banding Laboratory (hereafter banding lab) of the United States Geological Survey, which, using its own set of criteria to calculate longevity for birds whose ages are not known at the time of banding, assigned a minimum age of 27 years, 7 months. $3,11,18$

The ability to determine the age class of captured owls whose hatching year is unknown varies from species to species and all methods include uncertainty. In such cases the banding lab calculates longevity based on the date the bird was banded. If banded after the breeding season and before 1 January, the age is recorded as unknown and a minimum estimate of longevity would include the number of months since June (the banding laboratory assumes a June hatching date for all species) of the calendar year it was banded, plus the time passed from 1 January to the date of recovery.

Regardless of the method of calculation, this is the oldest wild Great Horned Owl on record. ${ }^{8,13}$ It is several years older than the two oldest individuals banded as nestlings ( 21 years, 4 months and 22 years, 2 months) that were mentioned in The Birds of North America account for this species. ${ }^{8}$ Longevity records of 17 years, 3 months and 20 years, 7 months for Great Horned Owls were listed in compilations of records of longevity of North American birds, ${ }^{3,11}$ and repeated in Carey and Judge's comprehensive compilation of records for birds and other vertebrate groups. ${ }^{2}$

No other species of owl in North America has been confirmed living longer in the wild. The next oldest owl was a Barred 
Owl, at 20 years, 2 months. ${ }^{.1}$ A Barn Owl banded as a nestling was stated to have lived for 34 years, but banding and recovery dates for this individual were not given. ${ }^{10}$ Indeed, life spans of other Barn Owls in North America based on the record above and subsequent records on file in the banding lab, revealed records of 11 years, 6 months and 15 years, 5 months. 3,9

Why calculate longevity? As a species characteristic, longevity is a rather inexact measurement, but because it has striking publicity value, it has been frequently quoted. ${ }^{16}$ Longevity estimates are subject to errors in record keeping and are influenced by the number of birds banded and the number of years in which the particular study was conducted. Large numbers of birds must be banded over many years, up to the theoretical limit of maximum lifespan, to increase the chances of recapturing or recovering individuals that have lived a long time. ${ }^{16}$ Nevertheless, longevity records have revealed differences between habitats, continents and life-styles. ${ }^{2,4} \mathrm{~A}$ detailed analysis of data from millions of banded birds determined that the observed longevity of birds relates significantly to population dynamics, that is, the longer a species lives, the higher the annual survival rate for both adults and young. ${ }^{14}$ This relationship is important for owl conservation because it is not often possible to band large numbers of owls, as Stuart Houston has done with nestling Great Horned Owls in Saskatchewan, making longevity records one of the best available approximations of annual survival rates for some species.?

\section{Acknowledgements}

We are indebted to Matt Dedrick for banding the Great Horned Owl so long ago and for providing Nero with detailed descriptions of the owl and information pertaining to the circumstances of its initial capture and banding and subsequent recapture. We also thank the personnel of the Assiniboine Park Zoo in Winnipeg for realizing the significance of this specimen and turning it over to Nero. Robert Barrow of The Manitoba Museum photographed the specimen.

1. AUSTING, G.R., and J.B. HOLT, Jr. 1966. The World of the Great Horned Owl. Lippincourt, Philadelphia.

2. CAREY, J.R., and D.S. JUDGE. 2000. Longevity records: life spans of mammals, birds, amphibians, and fish. Monograph on Population Biology, Number 8, Odense University Press, Odense, Denmark.

\section{CLAPP, R.B., M.K. KLIMKIEWICZ,} and A.G. FUTCHER. 1983. Longevity records of North American birds: Columbidae through Paridae. Journal of Field Ornithology 54:123-137.

4. FRY, C.H. 1980. Survival and longevity among tropical land birds. Proceedings of the Pan-African Ornithological Congress (1976), pp. 334-343.

5. GODFREY, W.E. 1986. The Birds of Canada. Second edition. National Museum of Canada, Ottawa.

6. HOUSTON, C.S. 1992. North America's oldest Great Horned Owl. Blue Jay 50:8890.

7. HOUSTON, C.S., and C.M. FRANCIS. 1995. Survival of Great Horned Owls in relation to the Snowshoe Hare cycle. Auk 112:44-59.

8. HOUSTON, C.S., D.G. SMITH, and C. ROHNER. 1998. Great Horned Owl (Bubo virginianus). In: Poole, A. and F. Gill (eds.). The Birds of North America, No. 372. The Academy of Natural Sciences, Philadelphia, and The American Ornithologists' Union, Washington D.C.

9. KENNARD, J.H. 1975. Longevity records of North American birds. BirdBanding 46:55 
10. KERAN, D. 1981. The incidence of man-caused and natural mortalities to raptors. Raptor Research 15:108-112.

11. KLIMKIEWICZ, M.K., and A.G. FUTCHER. 1989. Longevity of North American birds, supplement 1. Journal of Field Ornithology 60:469-494.

12. KREBS, CJ. 2001. Ecology. Benjamin Cummings, New York.

13. NERO, R.W. 1992. New Great Horned Owl longevity record. Blue Jay 50:91-92.

14. PAYEVSKY, V.A., and A.P. SHAPOVAL . 2000. Survival rates, life spans, and age structure of bird populations. Annual Reports of the Zoological Institute RAS. Zoological Institute, Russian Academy of Sciences, Universitetskaya nab. 1, St. Petersburg, 199034, Russia (http:// www.zin.ru/annrep/2000/17.html).
15. PITTAWAY, R. 1993. Subspecies of the Great Horned Owl. Ontario Birds 64-68.

16. ROWLEY, I., and E. RUSSELL. 1991. Demography of passerines in the temperate Southern Hemisphere. In: Perrins, C.M., J.-D. Lebreton, and Hirons, G.J.M. Bird Population Studies: Relevance to Conservation and Management. Pp. 22-44. Oxford University Press, Oxford.

17. TAVERNER, P.A. 1937. Birds of Canada. National Museum of Canada, Ottawa.

18. UNITED STATES GEOLOGICAL SURVEY. 2002. Bird Banding Laboratory web site: (http://www.pwrc.usgs.gov/bbl/ homepage/longvrec.htm).

19. ZEILIG, M. 1992. Park zoo forced to destroy oldest-known owl of species. Winnipeg Free Press, January 25, 1992.

\section{THE SECOND ROSS'S GULL OF MY LIFE WAS A FIRST FOR SASKATCHEWAN}

JAMES K. FINLEY, 10232 Summerset Place, Sidney, BC V8L 4X2

Dedicated to the memory of Wayne Harris, one of Saskatchewan's finest naturalists.

We drove down the road past the old Wise homestead, three biology students from the University of Saskatchewan, Wayne Harris, Wayne Renaud, and myself, and stopped at the "Wise Slough"* to study some shorebirds. It was 1971 or 72 . Renaud included some of our observations in his Birds of the Rosetown - Biggar District, though he didn't mention the flock of dowitchers. ${ }^{1}$ We argued over their identity so Harris and I collected a few for "study purposes", much to Renaud's chagrin.

Three decades after the dowitcher incident, on October 26th, 2002, I was driving down the same road past the Wise place with my brother-in-law, Brent Honeker, a local farmer, surveying the crops. It was a disastrous year, the fourth and most severe year of a deep drought; after a cold 